\title{
The Post-Larval Development of Loimia medusa Sav.
}

\author{
By \\ Douglas P. Wilson, B.Sc., \\ Student Probationer at the Plymouth Laboratory.
}

With 2 Plates and 7 Figures in the Text.

\section{CONTENTS.}

1. Istroduction

2 Methons.

3 Pelagid Stages-

(a) General Appearance . . . . . . . . . . 130

(b) The Development . . . . . . . . . 131

4. Botrom Stages-

(a) The Building of the Sandy Tube . . . . . . 134

(b) The Early Bottom Stages . . . . . . . . 136

5. The Снжтж-

(a) Development of the Bristles and Uncini . . . . . 138

(b) Comparison with Nicolea zostericola Ersted sec. Grube . . 140

6. Previous Records . . . . . . . . . . . . 142

7. Points of General Interest . . . . . . . . . . . . 143

8. Summart . . . . . . . . . . . . . . . . . . . . . 145

9. References . . . . . . . . . . . . . . . . . . 145

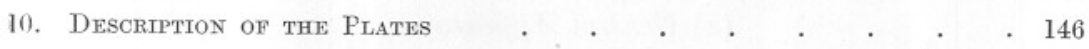

1. Introduction.

For many years a Terebellid larva, the genus and species of which were unknown to us, has been a conspicuous feature of spring plankton gatherings made in the Plymouth district. Immediately recognisable by its bulky gelatinous case it has frequently been a dominant form, and on account of its large tube has been responsible for increasing greatly the volume of the plankton samples obtained. It was of interest therefore to determine the species and to trace the main features of the development as far as this was possible. With this end in view a successful attempt was made to rear them, thus enabling the following contribution to our knowledge of larval Terebellids to be made. 


\section{Methods.}

On April 4th, 1927, and again on April 11th the plankton gatherings, particularly those made with the Young Fish Trawl, brought in by the s.s. Salpa from the neighbourhood of the Eddystone contained large numbers of this particular larva. Selected specimens in various stages of post-larval development were placed in a plunger-jar containing fresh unfiltered sea-water from outside the Breakwater and to this was added on two or three subsequent occasions a little Nitzschia from a pure culture kindly supplied by Dr. Allen. The jar was located in a window of north-westerly aspect, and in order to shield it from too much light a sheet of brown paper was tied round on the window side. On bright days a cardboard cover was placed on the top.

The larvæ were studied alive, the smaller forms in cavity-slips, the larger ones in open dishes. The drawings were made from these living larvæ while they were perfectly free to move about. This was done with the aid of a squared-net micrometer in the eyepiece, drawing in the first place on to squared paper. Care was taken to get the proportions as exact as possible, but on account of the constant movements and constrictions this was by no means an easy task. The different stages are illustrated at what was judged to be the mean of the varying degrees of contraction and all measurements likewise refer to this mean or resting condition. These drawings were subsequently checked, as far as was possible, by the examination of whole mounts of specimens narcotised with Menthol and fixed in Bouin. The uncini were drawn from larvæ flattened in Farrant's Medium.

\section{Pelagic Stages.}

(a) General Appearance.

In general appearance the body is fusiform, but the shape is constantly changing as the larva moves about in its tube. Dilatations followed by constrictions repeatedly pass along the body in either direction, and the larva now elongates now shortens as it twists and turns in its tube. The latter is a large cylindrical gelatinous mass several times the size of the larva (Plate I, Fig. 1), perfectly transparent and, indeed, difficult to see until it is disfigured by the sticking on of debris to its outer surface. Through this mass there runs from one end to the other what can best be described as a tunnel. In this tunnel the larva lives, poking its head out at one end and stretching forth its tentacles as it drifts about in the water. Every now and then it turns round on itself, and crawling through the tunnel appears at the other end. As the larva grows the tube is increased in size, or the larva may make a 
new one. This frequently happens in the plunger-jar, the young worm deserting its old case and building another. The secretion of the jelly is rapid, and by the next day the larva is once more encased in a substantial mass. When free in the water the creature can swim forward by rapid, vigorous lateral undulations of the body, the tentacles being thrown out to both sides.

The larva possesses little pigment and is very transparent, and the internal organs are clearly visible. The prostomium is speckled with dark brown, and in the later stages this pigment also occurs on the ventral shields with some specks of it on the tentacles and upper lip. The gut is greenish yellow or brown, the tint varying according to its contents. This showing up through the transparent body-wall is the predominating colour of the larva.

The number and arrangement of the eye-spots varies slightly, there frequently being two dark brown spots, a large one with a smaller one below, on each side of the prostomium.

\section{(b) The Development.}

The earliest larva seen was that shown in Plate I, Fig. 2. Just over a millimetre long it was already unmistakably a Terebellid. At this stage the median tentacle is budding forth in front of the prostomium above the great arch of the upper lip. Seven pairs of bristle-bundles are present, the first above the conspicuous statocyst, the last very small. Below each of the bundles, except the first, there is a long muscular process bearing distally a single uncinus of a larval type (Text-Fig. 4). These processes continue posteriorly, and five to six pairs are present behind the bundles. On the back there is a series of irregular nototrochs of short fine cilia, one nototroch to a segment. There is also a patch of cilia dorsally just behind the prostomium, a short lateral row below and anterior to the statocyst, and a scarcely visible row of very short fine cilia on the dorsal surface of the upper lip just in front of the eye-spots. A few rather short "sensory" cilia are present on the prostomium and around the anus. Similar cilia are also present on the tips of the tentacles of later stages.

The upper lip forms a kind of half-funnel at the bottom of which the mouth opens. Just inside the latter a prominent tongue-like process, really a thickening of the floor of the buccal cavity, is frequently turned forwards and downwards and then rotated back again. This organ is probably used in fashioning the tube. It is present in Lanice and is called by Elrington (3, p. 106) the "buccal organ." The œesophagus passes back to open into the stomach at.which point an enlargement of the gut takes place. The first part of the stomach is thick-walled, 
and this is followed by a thinner-walled portion, which passes imperceptibly into the intestine. The gut is longer than the body, and is looped or thrown into folds in the body-cavity within which it is suspended by threads of tissue passing from the body-wall. These are indicated in the drawings of the two earliest stages.

Various other internal structures are visible; these include the cerebral or dorsal glands behind the prostomium, the developing glands of the ventral shields, the heart, the muscles for moving the bristles, and just anterior to each statocyst a peculiar larval nephridium. This last is best seen at somewhat later stages (see Plate I, Fig. 3). It appears to open externally well up on the side of the body, but I have not paid any special attention to it. Later on (see Plate II, Fig. 1) it degenerates and disappears. This agrees with Meyer's view that the early larvæ of Terebellids possess a pair of temporary head-kidneys which ultimately degenerate and disappear (11, p. 662).

As development proceeds the larva increases in length and girth. The upper lip becomes relatively larger, the median tentacle elongates and the buds of others appear on each side. New tentacles usually arise alternately, first on one side and then on the other. This results in one side having one more tentacle than the other side, and its tentacles also are longer than the corresponding tentacles on the other side. This alternation may be either right or left, and in some cases it scarcely exists at all, the tentacles appearing simultaneously or almost simultaneously on each side. The tentacles become deeply grooved ventrally and the grooves ciliated. New segments are added posteriorly and these soon develop uncinigerous processes and irregularly broken nototrochs. New bristle-bundles arise behind those already formed and above the uncinigerous processes. Fig. 3, Plate I, shows a larva with five tentacles, eleven to twelve pairs of bristle-bundles and fifteen to sixteen pairs of processes bearing uncini. The other details are very similar to those already described for the earlier stage.

An important change now takes place. At about, or immediately after, the stage drawn in the last-mentioned figure the bristles above the statocysts are lost, and at the same time the uncinigerous processes below what was the second, but now becomes the first, pair of bristlebundles also disappear.

Development then proceeds steadily, fresh segments are added on behind, new tentacles appear and the old ones elongate. Bristle-bundles are formed until seventeen pairs are present, and then the parapodia change their character and develop into the abdominal type. Before this happens, however, and at a stage with about twelve pairs of bristlebundles and about seventeen pairs of uncinigerous processes (see larva 3 of diagram, Text-Fig. 7), the first pair of branchiæ appear above the 
statocysts a little dorsal to the position formerly occupied by the bristles which have been lost. About the same time swellings develop at the base of the uncinigerous processes, and a little later give rise to distinct tori as yet without uncini (see Text-Fig. 6).

Soon a fold grows out on each side just posterior to the statocyst and between it and the first thoracic chætæ. These folds develop into the fan-shaped flaps which are present below the second branchiæ in the adult. At about the same time a ridge arises ventrally just behind the mouth and passes up a little way on each side. This gradually grows out into a forwardly directed lamella to form the large post-oral platform so characteristic of the species (see larva 4 and subsequent stages in diagram, Text-Fig. 7). Uncini of the adult type (Text-Fig. 5) are now developing in the tori; these are dealt with in greater detail below (p. 139).

The second pair of branchiæ appear when all seventeen pairs of bristlebundles are present (Larva 5 of diagram) and the first pair of branchiæ are beginning to branch. The four anal papillæ arise as swellings, and are soon distinct.

A little later stage is shown on Plate II, Fig. 1, and if this drawing is compared with that on Plate I, Fig. 3, several important differences will be noted. The branchiæ and the above-mentioned head-folds have, of course, appeared and the anal papillæ are prominent. All the thoracic parapodia are present, and with the exception of the first pair are now provided with tori in which uncini of the adult type have developed. The first six pairs of tori have each a single row of uncini, the latter facing forwards (i.e. teeth directed towards the head), while the posterior ten pairs have each a double row with the uncini back to back. The larval hooks and the long processes on which they were situated have disappeared. These thoracic parapodia are followed by about fourteen pairs of the abdominal type, the most posterior of which are still very small and scarcely dififerentiated. There are now two irregularly broken nototrochs of fine short cilia on every segment behind the first eight bristle-bundles, with the exception of the most newly acquired segments near the anus where there is only one to a segment. The gut is straighter than formerly and the larval nephridia are degenerating and ultimately disappear. The ventral shields are more prominent, and the tentacles longer and more numerous. The total length-including that of the longest tentacle - is now approximately $7 \cdot 4 \mathrm{~mm}$.

All this time the larva has been floating about in its case of transparent jelly. This it continues to do until it has reached a stage about equivalent to that indicated in larva 6 of the diagram (Text-Fig. 7). It is impossible to give the exact age at this stage as the larvæ put into the plunger-jar varied considerably in this respect. We can say, however, that in the plunger-jar it took roughly three months to pass from the earliest stage 
seen (Fig. 2, Plate I) to the stage at which they begin life on the bottom, because several of the larvæ placed in the jar on April 4th and April 11th were scarcely any older than the earliest one described and the last larva had settled down by July 14th. In the sea development is possibly much quicker, and there may be considerable variation depending on the amount of food each individual is able to obtain. In the plunger-jar they fed largely on diatoms.

\section{Bottom Stages.}

\section{(a) The Building of the Sandy Tube.}

When the young worms reach the stage at which they are ready to settle on the bottom they exhibit an impulse to build, and if sand be denied them they will collect stray cotton hairs, fæcal matter, and other debris and attempt to build tubes on the sides of the jar. As soon as this was noticed in the older larvæ small pots of sterilised sand were placed in the plunger-jar, and those which had already settled down on the glass were carefully removed to these where they began to build at once. Subsequently other larvæ as they became ready to build settled in these pots, while others made use of scattered sand grains spilt on the bottom of the jar, or, if near enough, actually collected grains from the pots with their tentacles and so constructed tubes along the glass. The latter tubes were usually incomplete, the glass forming one side, but it was nevertheless coated over with the same cement as was used to stick the particles of sand together.

Larvæ would readily build in small dishes while under the microscope. As soon as it comes to rest on the bottom a larva stretches forth its tentacles and searches the immediate neighbourhood. Should the tentacles come into contact with sand grains these are immediately seized and conveyed towards the mouth. Sometimes the tentacles drag them along, often they cause them to travel down the deep grooves, a convenient edge of each piece sliding along in the groove. In this way a single tentacle may convey more than one grain at once, several sliding down its groove one after another. As much as possible of each is taken into the space between the upper lip and post-oral platform and into the mouth. If the piece is a flat one the upper lip and mouth are applied after the fashion of a sucker. The buccal organ is meanwhile seen to be working vigorously. After two or three seconds the piece, which has doubtless been coated with cement, is pushed or pulled into position by the head and anterior part of the body, the upper lip clinging tight hold all the time. As soon as it is in place it is released and another fragment is then immediately dealt with in the same way. When the grain is a large one the tentacles assist the lips to hold it. In this manner 
a length of sandy tube is rapidly constructed away from the mouth of the larval gelatinous case, and it is attached to whatever the substratum happens to be. As the sandy tube is lengthened the larva gradually quits its transparent case until it has left it altogether. Quite frequently after constructing a fair length of tube in one direction the worm will turn round and start building in the opposite direction from the other end of its old pelagic home.

There is very little selection of the grains used, few being discarded. This is different from Lanice conchilega Pallas (the larvæ of which I have also reared) which appears to be a little particular, taking greater

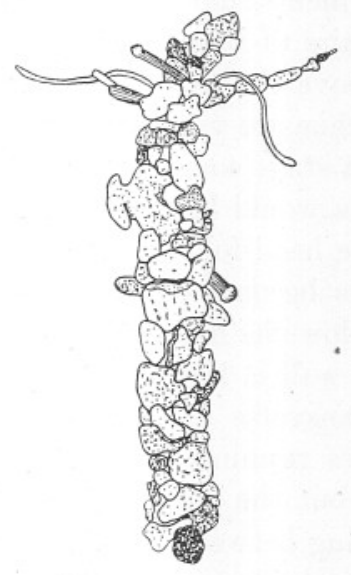

Text-Fig. 1.-Anterior portion of sandy tube constructed by an early juvenile of Loimia medusa Sav. $(\times 5$. $)$

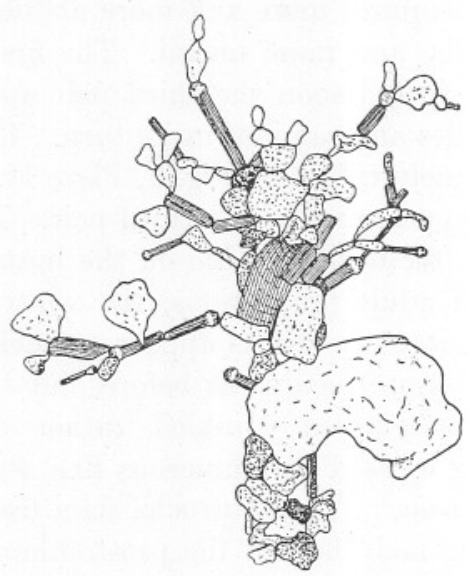

Text-Fig. 2.-Anterior portion of a similar tube to that of Fig. 1, but with a more elaborate frill. $(\times 5$.)

care to make the pieces fit. Loimia takes less trouble over it, and uses a much wider range in size of fragments. Thus it leaves more and larger gaps between the pieces forming the wall of its tube, and through these gaps the worm can be seen. Its tube is also more pliable and fragile than that of Lanice, and the grains are not immovably cemented one to another; a considerable degree of bending can take place between them.

In about half an hour a Loimia larva can construct a sandy tube about twice its own length (excluding the tentacles). During these building operations small fragments are sometimes accidentally swallowed, but they quickly pass along the gut and are voided at the anus.

The anterior end of one of these tubes is shown in Text-Fig. 1. At the time of drawing it was about one month from the larva having first settled down. At this age the tubes vary in length between twenty and thirty millimetres, and the young worms inside are similar to the stage shown in Fig. 2, Plate II. This particular tube was just getting a frill put on 
its anterior end, and in the figure two tentacles of the larva are seen protruding from the opening. A rather older tube with a fairly elaborate frill is illustrated in Text-Fig. 2. Small Echinus spines are largely used in its construction, and the frill, like the tube, is quite pliable. Note the wide range in size of the particles used in the formation of the tubes.

\section{(b) The Early Bottom Stages.}

After settling down no marked change occurs in the sequence of develop-. ment, it proceeds steadily as before. The young worm increases in size and acquires more and more abdominal segments, more bristles in each bundle, and more uncini. The first two pairs of branchiæ continue to branch and soon the third pair appears above the first pair of bristlebundles and ramifies in its turn. The branchiæ are very contractile and are finely ciliated. Fig. 2, Plate II, shows a stage some little time after the appearance of the third pair. This larva would be about five weeks old after beginning life on the bottom. The head-folds grow until they reach adult proportions, the ventral shields become prominent, and a few more eye-specks appear on each side below the main eye-spot. Pigmentation remains as before, but the body-wall is less transparent and the integument wrinkled, rather strong transverse grooves and ridges being crossed by numerous fine wavy ridges running in a longitudinal direction. The nototrochs soon disappear, but the anterior dorsal part of the body behind the prostomium extending between the bases of the branchiæ downwards on each side to about the level of the parapodia and backwards to about the sixth pair of bristle-bundles has the appearance of being evenly ciliated. The short fine cilia may, however, be arranged in numerous close transverse rows, but of this it is extremely difficult to be certain. There are also patches of cilia on the prostomium.

A sketch of the ventral view of the head of the same specimen, as is shown in Fig. 2, Plate II, is given (Text-Fig. 3). This sketch shows the upper lip widely spread, and the fine cilia with which its inner surface is covered are indicated passing down into the œsophagus. The buccal organ is drawn back in the position of rest. Below is the post-oral platform, which rises as a forwardly projecting flap on either side of the head and passes downwards to form a broad shelf below the mouth. It is slightly indented in the middle line, and is finely ciliated on its outer surface. In the drawing it is represented as turned backwards. Behind are seen the ventral shields and the flap on each side below the second branchia. These flaps are also finely ciliated on their outer surfaces.

For a short time after first making a sandy tube the young worm can secrete a larval case if it be removed and placed in a dish where there is nothing for it with which to build. It soon loses this ability, and about 
this time the cerebral or dorsal gland degenerates and disappears. Elrington (3) has shown that in Lanice conchilega Pallas the dorsal gland is very probably that which furnishes the material for the formation of the larval tube, and that in that species also it disappears after the larvæ have settled down.

By the end of October several of the young Loimia worms were still living in the same plunger-jar without change of water, and were in a much more advanced condition than the oldest specimen illustrated. Their tubes averaged about ten centimetres long with posterior diameters of roughly two millimetres, widening gradually to about three millimetres

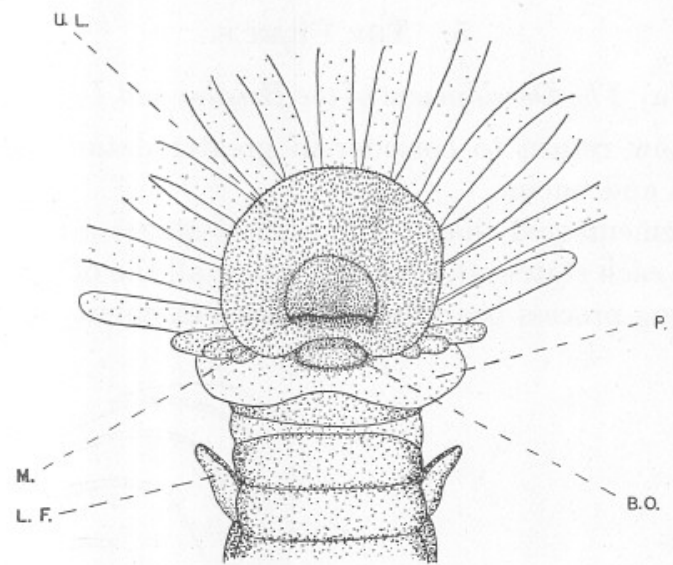

Text-Fic. 3.-Ventral view of the head region of the specimen drawn in lateral view on Plate II, Fig. 2. The upper lip is widely extended and stretched rather forwards and downwards (see p. 136). From life. $(\times 32 \cdot 5$. $)$

B.O. Buccal organ. F. Post-oral platform.

L.F. Lateral head-fold. U.L. Upper lip.

M. Mouth.

at the anterior ends, which were adorned with large frills. The worms themselves were rather more than two and a half centimetres long (excluding the tentacles) and had about seventy chætigerous segments. The numerous tentacles were very slender and extensile, and could stretch out to a length two or three times that of the body. All the branchiæ were much branched and tree-like, the anterior pairs most so, and the pulsations of the red blood through their blood-vessels could be seen very distinctly. The body-wall was less transparent than formerly and of a very pale yellow colour by reflected light, but the general outline of the gut could still be seen through it though no internal detail was distinct. The speckled brown pigment had the same sort of distribution as before, and there were several rather irregular dark brown eye-spots 
in a transverse row on each side of the prostomium. The tori were longer in a dorso-ventral direction, and contained more uncini of the adult type; some of the hooks had six or seven teeth. There were four long anal papillæ.

The last remaining larva was fixed on December 5th. Without the tentacles it was approximately four centimetres long and correspondingly bulky, and it had eighty-one chætigerous segments. Its tube was twelve centimetres long with a posterior diameter of two millimetres and an anterior diameter of four millimetres. There were frills on both ends.

\section{The Сhжтж.}

(a) The Development of the Bristles and Uncini.

We must now return to consider in greater detail the development of the bristles and uncini.

It will be remembered that in the earliest stages a bristle-bundle was present above each statocyst, and that below all the other bristle-bundles there was a long process bearing at its distal extremity a single uncinus.

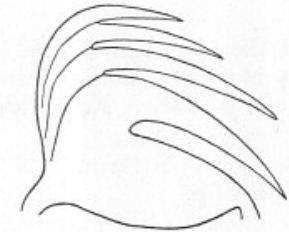

Text-Fig. 4.-Uncinus of Larval Type. $(\times 2600$. $)$

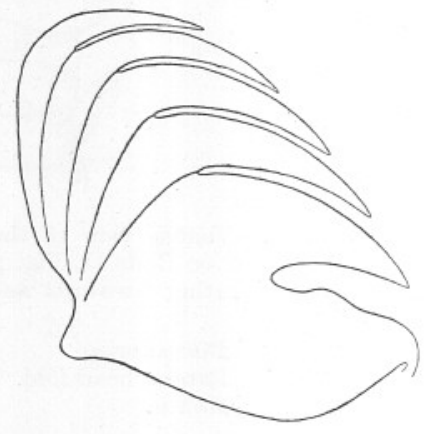

Text-Fis. 5.-Uncinus of Adult Type from an early bottom stage. $(\times 2600$.

This uncinus is a larval kind (Text-Fig. 4) with longer and more slender teeth than that of the adult, but it is nevertheless distinctly of the Loimia pattern. Each bristle-bundle has two chætæ, the anterior one long, slender, and very pliable, the posterior short and with a swollen extremity (Text-Fig. 6). Each bundle as it develops acquires these two types of bristles until the eleventh (tenth adult) pair form, and then from there posteriorly only slender pointed bristles are produced.

It is interesting to watch the way in which these larval bristles are used. When a bundle is pressed against the wall of the tube the soft jelly is indented at that place. The long tapering bristle on account of 
its flexibility is bent into a curve until the knob of the other bristle also comes into contact with the jelly. This bristle does not bend, but the knob prevents it from piercing the tube wall. The jelly is now strongly indented, and in this way the bristles are doubtless able to get a pushing grip on the soft and presumably rather slippery internal wall of the tube.

While the bristle-bundles are thus pushing organs, the uncinigerous processes have exactly the opposite function. The hooks are used as anchors on the wall of the tube, and with them the larva can pull itself backwards. By adjusting the degree of antagonistic action between bristles and hooks the larva clings firmly to its floating home, and can safely stretch its head and tentacles out of one of the openings.

The disappearance of the first pair of larval bristle-bundles and uncinigerous processes has already been mentioned (see p. 132). As the larva grows older the tori gradually arise as swellings and increase in size, but are at first without uncini (Text-Fig. 6). They develop above the processes bearing the larval hooks, but in such a manner that these latter come to be seated at their lower extremities. At about the stage indicated in Larva 4 of the diagram (Text-Fig. 7) uncini first become visible in the tori, and it is interesting to note the order in which they develop. I have failed to trace a regularity comparable to that which Herpin (9, p. 204) found in Nicolea zostericola Ersted sec. Grube, but certain generalities may be stated. The M.P. Muscular process bearing seventh and immediately succeeding pairs of tori rapidly acquire more hooks than

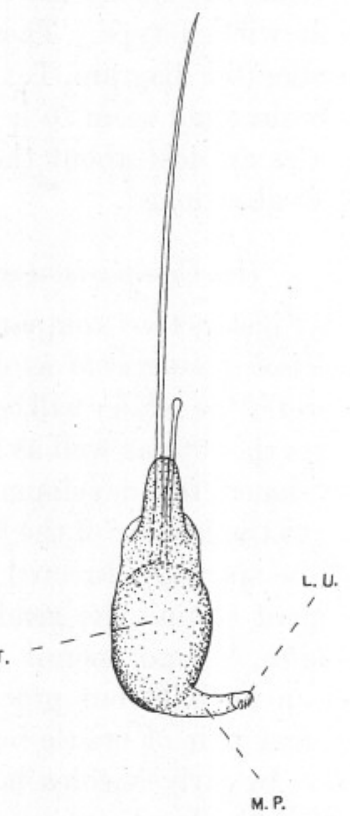

TEXT-Fig. 6.-An anterior thoracic parapodium from the left side of a post-larval Loimia medusa Sav. $(\times 260$.

L.U. Uncinus of larval type. uncinus.

T. Developing torus before appearance of uncini.

doubtedly correlated with the fact that in the adult the first six pairs have only a single row, while the seventh and posterior pairs have each two rows of hooks. In the latter one or two hooks of the anterior row generally appear first and then those of the second row begin to appear. The hindermost tori lag behind possibly because they are the last to develop. By the time the larva is ready to abandon planktonic life the uncini in each torus are fairly numerous, there being approximately 
twelve to twenty in each of the six anterior pairs and ten or twelve in each row of those tori with double rows, except in the most posterior ones which have only about half that number. The double rows of uncini are opposed back to back. The abdominal feet have on an average four hooks each, but sometimes as many as six. All these uncini are of the adult type (Text-Fig. 5) and were the first definite proof of the identity of the species. The larval uncini and processes are lost shortly after the appearance of the second branchiæ.

While the hooks have been appearing so have new bristles of the adult winged type. These, as a rule, appear first in the most anterior bundles (see diagram, Text-Fig. 7), and gradually increase in numbers, but there does not seem to be any regular order of development. The larval bristles are lost about the same time as the larval hooks, before pelagic life is abandoned.

\section{(b) Comparison with Nicolea zostericola Ersted sec. Grube.}

An instructive comparison can now be made with the development of Nicolea zostericola as described by Herpin (9), and this will be made clearer if the reader will consult that writer's schematic figure of successive stages (p. 206) as well as my diagram (Text-Fig. 7). As has already been mentioned the development of the uncini is scarcely comparable, and it is to the history of the first three segments after the head that attention will be specially directed. In Loimia what may be regarded as the first segment behind the head possesses in the early stages a pair of bristlebundles, but no uncini. Each bundle of the pair immediately following has an uncinigerous process situated below. These processes as well as the first pair of bristle-bundles are, it will be remembered, subsequently lost. In early Nicolea larvæ, on the other hand, the first two segments behind the head possess paired bristle-bundles, but no uncini, while the third segment carries a pair of bundles with a single uncinus below each. On further development the bundles on the first two segments and the uncini on the third segment are lost. It will be noticed that the important difference between the two forms is that Nicolea has two pairs of temporary bristle-bundles while Loimia has one. Which of these two pairs is homologous with the single pair of Loimia?

Some indication of the probable answer to this question may be obtained by considering the position of the branchiæ. In Nicolea there are two pairs of these, and they arise on the first two segments near the positions formerly occupied by the temporary bristles. In Loimia there are three pairs, the first pair arising just dorsal to the position where the temporary bristles were situated, the second pair between these and the first pair of adult (second larval pair) thoracic bristles. The third pair arise above the latter. If we now make the very probable assumption that the 
1

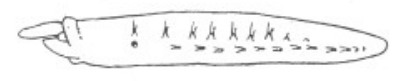

2

3

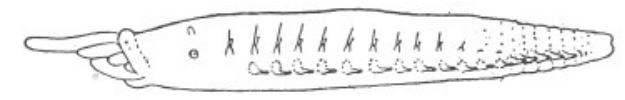

4

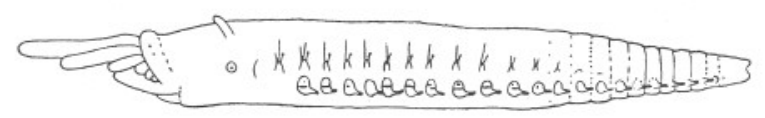

5
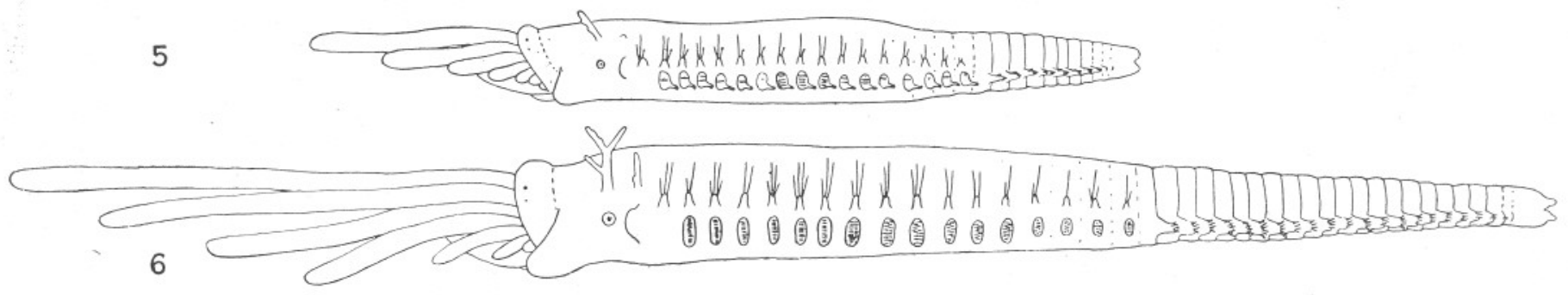

'I'ExT-FiG. 7.-Diagram of post-larval pelagic stages of Loimia medusa Save. to show the development of bristles and uncini, tentacles, head-folds, branchia, and anal papilla. Drawn from mounted specimens. $(\times 19 \cdot 5$. $)$ Explanation in the text.

$\stackrel{\rightleftarrows}{\rightleftarrows}$ 
branchiæ of Nicolea are homologous with the first two pairs of branchiæ of Loimia and that the corresponding segments on which they arise are homologous, we arrive at the interesting conclusion that in Loimia the second pair of larval bundles (first pair adult) are really homologous with the third 'arval pair of Nicolea, which are also the first adult pair of that worm. That this is so seems to be confirmed by the fact that these are the segments in both species which possess temporary uncini that are lost about the same time as the bristles. It seems probable then that Loimia, during its evolutionary history, has lost a pair of larval bristle-bundles between what are now its first and second larval pairs. At all events a segment does appear to exist between these two latter, for it is on this segment that the second pair of branchiæ and below them the lateral folds of the head arise.

\section{Previous Records.}

It remains to consider whether the larvæ of Loimia have been observed and described before. The most important record in this respect is undoubtedly that of Andrews (2) for the sea off the coast of North Carolina. In the systematic part of his paper he describes (p. 298) what he believes to be a new species of Loimia, which he found under stones on the shore near Beaufort. This species he named L. turgida. On Plate XVIII he gives a rough sketch (Fig. 46) of a Terebellid larva he found abundantly in the plankton and which he says is that of his L. turgida. By reason of the thick gelatinous tube indicated in this figure and the fact that the larva possessed a pair of prominent statocysts " anterior to the first pair of setæ" (p. 300) I have no doubt that he was correct. Unfortunately he gives no reasons for his identification, but it is possible that he may have observed the shape of uncini of the adult type in the later larval stages, but if so he makes no mention of the fact.

Fauvel (4, pp. 57 and 71) has made the suggestion that the Terebellid larva figured and described by Agassiz as the larva of Terebella fulgida Ag. (1, Plate VII, Fig. 19, and p. 320) is possibly identical with Andrews's Loimia turgida larva. This is quite possibly the case, but Agassiz's description is too meagre and his figure not detailed enough to be certain on the point. The fact that this larva possessed a pair of statocysts and showed alternate development of the tentacles suggests that it may possibly belong to this genus, but, on the other hand, Agassiz states that these larvæ "build their cases very late" (he does not say what kind of case) " and frequently leave them to climb about on eel-grass, piles, etc." Moreover, he states that " the first ring having dorsal setæ has also a row of hook-shaped bristles," which is not the case in Loimia medusa at least. He gives a figure of one of the hooks (Fig. 19a), and it 
certainly has some resemblance to the adult type of hook of $L$. medusaas was pointed out by Fauvel - apart from the fact that he indicates no teeth beyond the large one next to the base. His figure rather suggests that he was doubtful about the existence of other teeth. He also states that " the eyes are still in prominent clusters and not yet formed into a ring round the collar, as they are arranged while gradually disappearing.", This early clustered appearance is, I think, explained by the fact that the eye-spots, particularly the smaller ones, show little if any difference from the other pigment spots scattered over the prostomium, and as there is considerable variation among individuals in the way in which this pigment is distributed the clustered appearance could easily be produced. In the early stages only the large eye-spot on each side can be said to be really definite, and is still distinctly visible in stained and mounted specimens.

\section{Points of General Interest.}

A few final points of general interest remain. McIntosh (10) separates our British Loimia from Loimia medusa Sav. because of a slight difference in the form of the uncinus from that of a Mediterranean specimen of the genus which he thinks is probably Savigny's species, and makes a new species Loimia montagui. The hooks of the latter "differ from those of the Mediterranean species, which have a process on the edge of the base beneath the main fang, and the curvatures also differ" (p. 149). Now if reference is made to my figure of the adult type of uncinus it will be observed that there is a rounded swelling in the same position as the process on the base of the uncinus of the Mediterranean specimen, as illustrated by McIntosh (10, Vol. IV, Plate CXXVI, Fig. 1b). It is true that it is by no means as pronounced a tooth as is shown in the latter figure and I have not seen one as prominent as is there illustrated, but it is an intermediate condition between the two types. Moreover, not all the uncini, even in the same torus, of the latest stage to which I have reared my larvæ bear even this slight swelling, in many the base below the great tooth is quite smooth like that of $L$. montagui McI. The uncini in other respects, such as curvature, also differ slightly one from another. The same remarks hold true for uncini from the same torus of an adult specimen I have examined. There again they vary from a smooth base to one with a tooth nearly as strongly developed as that shown in McIntosh's figure of a hook from L. medusa Sav. and the curvatures also vary slightly. Fauvel has pointed out (5, p. 146), from an examination of specimens from San Thomé, the Casamance, the Red Sea, and the Persian Gulf, that this basal tooth is less evident the larger the specimen and suggests that it disappears with wear. $\mathrm{He}$ further remarks on the danger of basing new species or varieties on 
such unimportant and variable characters. Under these circumstances I do not think that at present we can regard $L$. montagui McI. as a distinct species from $L$. medusa Sav., and for this reason I have retained the latter name in this paper. In any case the name $L$. montagui cannot be retained for this species as it has already been given by Grube (8, p. 224) to a Loimia from the Philippines.

Both Gravier (7, p. 224) and Fauvel (4, p. 70) have noticed that in young specimens of Loimia of about one or one and a half centimetres long the uncini have more than one row of teeth near the apex, whereas the adults have, of course, only one row. This is also the case with some, but by no means all, of the abdominal uncini of my specimens of about that size, but I have not observed it in thoracic hooks except in very early stages when uncini of the adult type were just appearing. All hooks of the larval type had the apical teeth in two or three rows. The figures of adult and juvenile hooks which Gravier gives ("', p. 224, Figs. 396-399) of specimens of $L$. medusa Sav. collected in the Red Sea, are rather different from the hooks of my adult and juvenile specimens. It must be noticed in connection with what has been said in the preceding paragraph that Savigny obtained his original specimens in the Red Sea. Gravier's figure of the adult hook differs from my specimens chiefly in the curvature; he shows no process on the base below the great tooth, but indicates one in his figure of a hook from a young specimen. Gravier also mentions that in his young specimens there was a temporary lobe on the third segment that was not present in the adults. I have seen no such lobe in my specimens.

In this district Loimia usually lives in banks of shell-gravel below lowwater mark, and is rarely found on the shore even at the lowest ebb of spring-tides. Portions of their wide (about $1 \mathrm{~cm}$. in diameter) tubes are frequently brought up by the dredge, but the living animal itself is extremely rarely obtained. I have not, in fact, yet seen a living adult specimen, but Dr. Allen has kindly allowed me to examine and remove some of the uncini from a damaged preserved specimen obtained here many years ago. On the same dredging grounds the tops of the tubes of Lanice conchilega are also frequently obtained, but the worm itself very seldom. From this we can only conclude that the tubes penetrate down to at least a foot or more, and the worms at the least disturbance retreat to the bottom too deep for the dredge to get them.

While this paper has been in the press Fauvel has published the second part of his valuable work on the polychæte fauna of France (6), and in this part he describes the Terebellids. Unfortunately owing to his grave doubts (expressed on p. 293) as to the existence of Loimia near Plymouth he has omitted a description of this species. I immediately wrote to him, enclosing a copy of the MS. of this paper, and 
he kindly replied, stating, "I am sorry I did not include Loimia in my Fauna, for your letter furnishes me with the clear evidence which, till now, I wanted of the occurrence of Loimia near Plymouth."

In conclusion, it is a pleasure to express my thanks to Dr. Allen for his help and stimulating interest in this work, and to the Staif of the Laboratory also for many kindnesses. The major portion of this work was done while holding a Graduate Research Scholarship from Manchester University and a Maintenance Grant from the Department of Scientific and Industrial Research, and these institutions also I wish to thank.

\section{SUMMARY.}

1. The larva of a Terebellid which is very common in plankton from the Plymouth district during spring has been reared and proved to be the young of Loimia medusa Sav. This larva is characterised by its very large gelatinous tube.

2. The development of the external structures is described from a stage in which the first tentacle was just appearing to a juvenile stage in which all the main characters of the adult had been assumed.

3. The building of the first sandy tube on the bottom is described.

4. The development of the bristles and uncini are dealt with in some detail and a comparison made with the corresponding development in Nicolea zostericola. Evidence of the suppression of a pair of larval bristlebundles in Loimia is indicated.

5. Previous records of Loimia larvæ are discussed.

6. McIntosh's separation of our British Loimia to a new species, L. montagui, is shown to be probably unjustified.

\section{REFERENCES.}

1. Agassiz, A. 1866. On the Young Stages of a Few Annelids. Ann. Lyceum Nat. Hist., New York. Vol. VIII.

2. Andrews, E. A. 1891. Report upon the Annelida Polychæta of Beaufort, North Carolina. Proc. U.S. Nat. Mus. Vol. XIV.

3. Elrington, G. A. 1909. Some Points in the Structure of the Larva of Lanice conchilega. La Cellule. T. 25.

4. Fauvel, P. 1907. Recherches sur les Otocystes des Annélides Polychètes. Ann. des Sci. Nat. Zool. 9e série. T. VI.

5. Fauves, P. 1914. . T Annélides Polychètes de San-Thomé. Arch. Zool. Expér. et Gén. T. 54. 
6. Fauvel, P. 1927. Faune de France. 16. Polychètes sédentaires.

7. Gravier, C. 1906. Contribution à l'Étude des Annélides Polychètes de la Mer Rouge. Nouv. Arch. Mus. Paris. 4e série. T. VIII.

8. Grube, E. 1878. Annulata Semperiana. Mém. Acad. Imp. Sci. St. Pétersbourg. T. XXV.

9. Herpin, R. 1925. Recherches Biologiques sur la Reproduction et le Développement de quelques Annélides Polychètes. Bull. de la Soc. des Sci. Nat. de l'Ouest de la France. $4^{\mathrm{e}}$ série. T. V.

10. McIntosh, W. C. 1922. A Monograph of the British Marine Annelids. Ray Society. Vol. IV. Pt. 1.

11. Meyer, E. 1887. Studien über den Körperbau der Anneliden. Mitth. a. d. Zool. Station zu Neapel. Bd. VII.

\section{DESCRIPTION OF THE PLATES.}

\section{LIST OF REFERENCE LETTERS.}

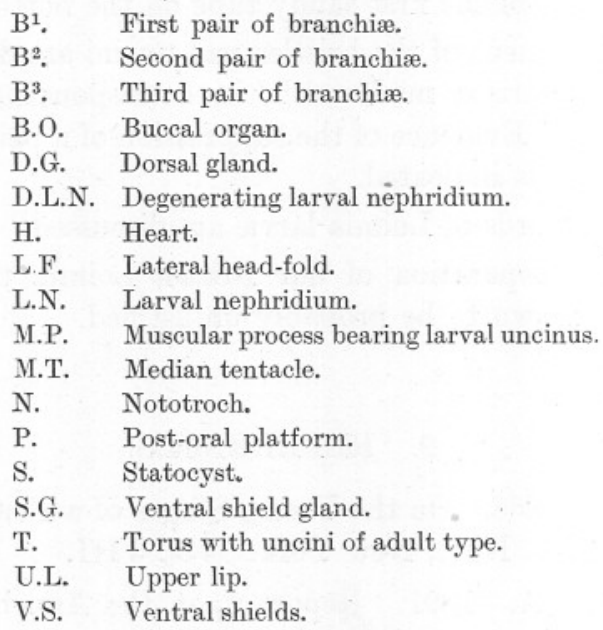

\section{PLATE I.}

FIG. 1.-Early post-larva of Loimia medusa Sav. inside its gelatinous tube. $(\times 9 \cdot 75$. $)$

FIG. 2.-The earliest post-larva seen (see p. 131). Lateral view from life. $(\times 78$.)

Fia. 3.-An early post-larva with a fairly long median tentacle and two lateral tentacle buds on each side (see p. 132). Lateral view from life. $(\times 78$. 
PLATE I.

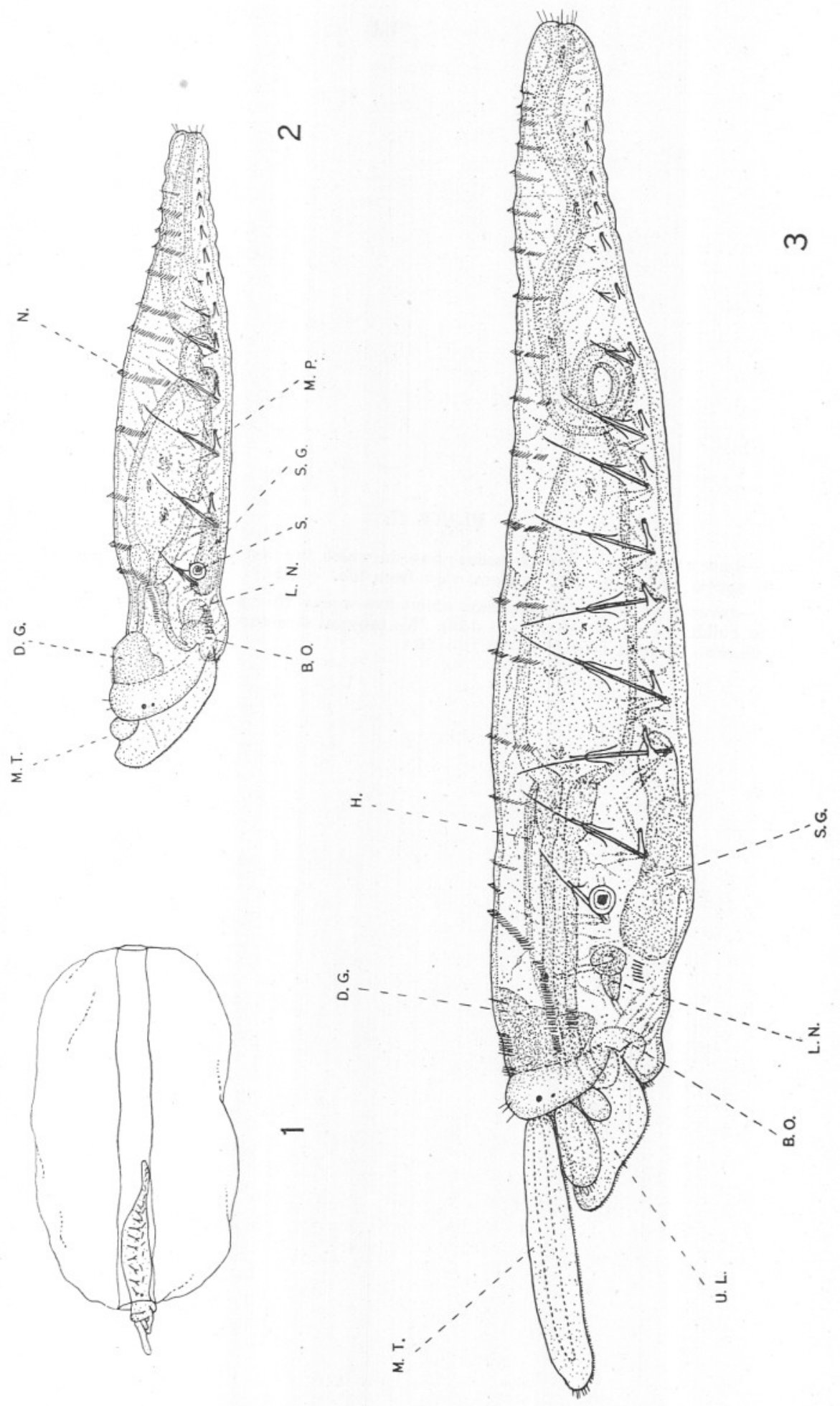




\section{PLATE II.}

FIG. 1.-Late post-larva of Loimia medusa Sav. in which the first two pairs of branchiæ are appearing (see p. 133). Lateral view from life. $(\times 26$.)

Fig. 2.- Juvenile of Loimia medusa Sav, about five weeks after settling on the bottom and building a sandy tube (see p. 136). No internal structure except the statocyst is shown. Lateral view from life. $(\times 26$.) 
PLATE II.

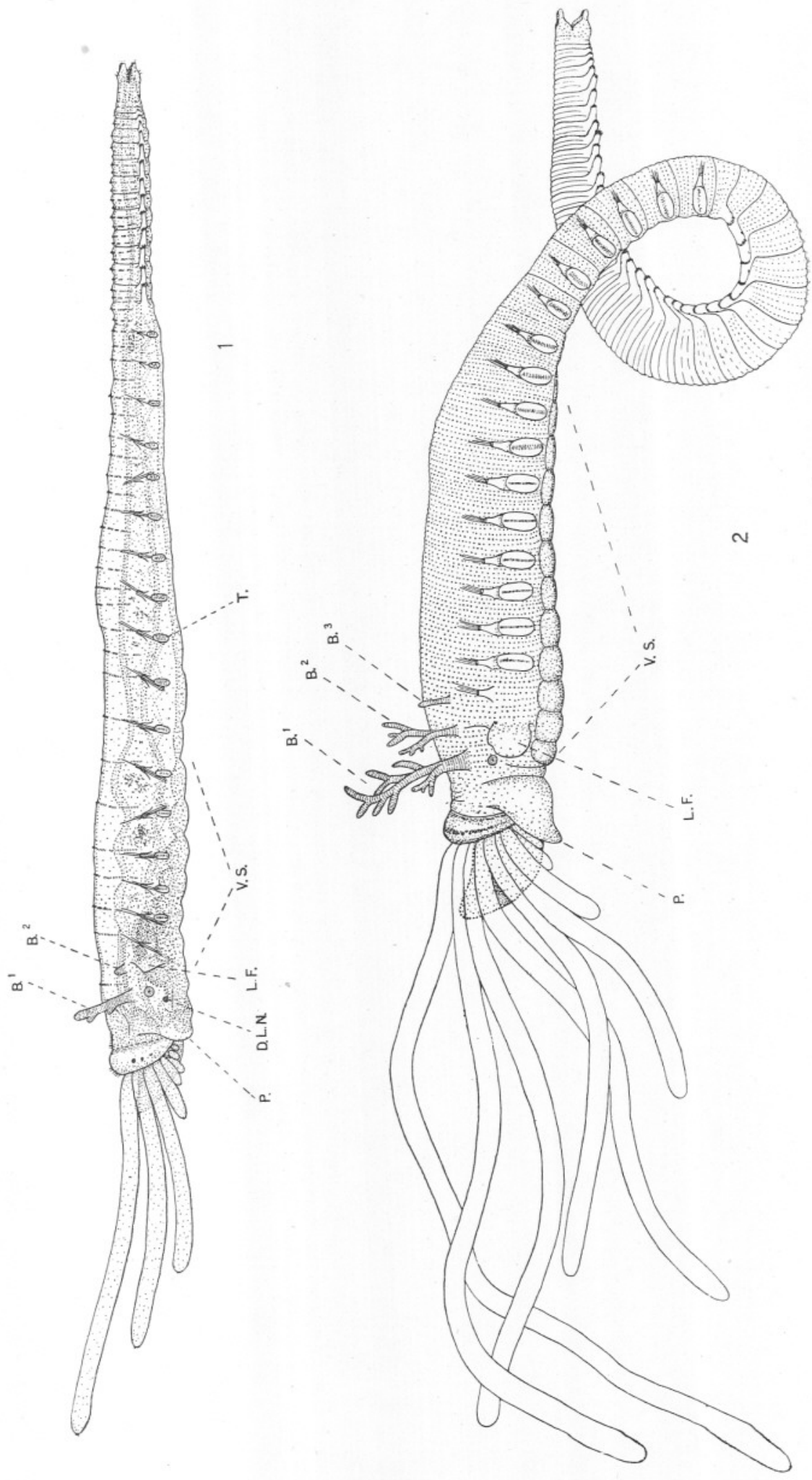


